\title{
Entrepreneurship and universities
}

\author{
David B. Audretsch
}

Institute for Development Strategies, Ameritech Chair of Economic Development, Indiana University, 1315 East 10th Street, SPEA Room 201, Bloomington, IN 47405, USA Email: daudrets@indiana.edu

\begin{abstract}
This paper examines the link between universities and entrepreneurship. The paper finds three distinct ways that universities influence entrepreneurship - technology transfer, knowledge spillovers and entrepreneurship capital.
\end{abstract}

Keywords: universities; entrepreneurship; technology transfer; knowledge spillovers and entrepreneurship capital.

Reference to this paper should be made as follows: Audretsch, D.B. (2017) 'Entrepreneurship and universities', Int. J. Entrepreneurship and Small Business, Vol. 31, No. 1, pp.4-11.

Biographical notes: David Audretsch is a Distinguished Professor and Ameritech Chair of Economic Development at Indiana University, where he is also serves as Director of the Institute for Development Strategies. He also is an Honorary Professor of Industrial Economics and Entrepreneurship at the WHU-Otto Beisheim School of Management in Germany and a Research Fellow of the Centre for Economic Policy Research in London. He is a member of the advisory board to a number of international research and policy institutes, including Chair of the Deutsches Institut fuer Wirtschaftsforschung Berlin (German Institute for Economic Analysis Berlin), Chair of the Stifterverband fuer die Deutsche Wissenschaft (Foundation for the Promotion of German Science), New York Academy of Sciences, the Swedish Entrepreneurship Forum, and the Jackstädt Centre for Entrepreneurship in Wuppertal, Germany.

This paper is a revised and expanded version of a paper entitled 'The role of the university in the entrepreneurial society' presented at the IECER Conference, Montpellier, France, 25 February 2015.

\section{Introduction}

A generation ago, few thought that universities had much, if anything to do with entrepreneurship. The hard-earned freedom of the university won by the great German philosopher, scientist and scholar, von Humboldt, ensured that the university was not only liberated from the dictates of the church and state, but it guaranteed the value and primacy of 'knowledge for its own sake', rather than knowledge because it provides some value for society or the economy.

Copyright (C) 2017 Inderscience Enterprises Ltd. 
But times change, the past quarter century has seen the evolution of the university from the model championed by von Humboldt to what some refer to as the entrepreneurial university or the university for the entrepreneurial society (Audretsch, 2007). A large and detailed literature has emerged identifying the important contribution that universities can play through technology transfer in generating innovative activity. The purpose of this paper is to suggest, however, that technology transfer is only part of the story. In fact, there are two other key ways that universities influence entrepreneurship - knowledge spillover entrepreneurship and entrepreneurship capital.

In the following section the link between entrepreneurship and technology transfer at universities is examined. The third section provides an analysis of the role played by universities in knowledge spillover entrepreneurship. The contribution that universities make to entrepreneurship capital is identified in the fourth section. Finally, in the last section, a summary and conclusion are provided. In particular, this paper suggests that the contribution that the contemporary university makes to entrepreneurship consists not just of a sole dimension, technology transfer, but rather three dimensions, which also includes knowledge spillover entrepreneurship and entrepreneurship capital.

\section{Technology transfer}

Technology transfer generally refers to technology which is created and owned by a university which is transferred to a private or non-profit organisation for a price, which, in principle, reflects the value of that technology. Passage of the 1982 Bayh-Dole Act in the USA greatly facilitated technology transfer by clearly and unequivocally assigning the intellectual property rights of any and all technologies resulting from federally funded research to the university where that research was funded and undertaken (Phan and Siegal, 2006; Aldridge and Audretsch, 2010, 2011).

The principal institutional mechanism facilitating and enabling university technology transfer has been the office of technology transfer, or TTO, which has had a rapid diffusion not just throughout the USA but across the world. The TTO at a typical university serves as the broker between technology resulting from university research and its commercialisation through private interests. The main instruments for technology transfer have been patented inventions, licensed technologies and new ventures (Link and Siegel, 2005; Link et al., 2007). Identification and measurement of university technology transfer has been facilitated by the Association of University Technology Managers (AUTM) in the USA, which provides systematic and comprehensive measurement of the activities of each university's TTO (Association of University Technology Managers, 2004).

The link between university technology transfer and entrepreneurship depends upon what exactly is meant and understood by 'entrepreneurship'. According to Audretsch et al. (2015), there are actually three distinct ways that entrepreneurship is understood to mean in the scholarly literature on entrepreneurship. The first meaning or understanding of entrepreneurship is based on behaviour. As Shane argues, entrepreneurship means exhibiting a type of behaviour that recognises, discovers or creates opportunities along with taking advantage or exploiting those opportunities. The behavioural view of entrepreneurship is organisation free, in that it can apply to any organisation or firm, or sub-group or team, as well as to any individual or group of individuals. 
University technology transfer can and does have a large impact on entrepreneurship, when it is viewed as behaviour. The bulk of technology transfer activities involve licensing technologies developed at universities to generate innovations at companies. Such technology transfer revolves around opportunities created and recognised by both the university and companies, as well as commercialised and exploited by private companies.

Markman et al. (2005) shows that the main priority and focus of the TTOs is on licensing patented technologies from the universities. According to Markman et al. (2005), the mission statement explicitly lists 'licensing for royalties' in $78.72 \%$ of the offices of technology transfer surveyed, 'intellectual property protection and management' in $75.18 \%$, and 'facilitate disclosure process' (of university scientists and other employees) in $71.63 \%$ of the offices of technology transfer surveyed. Mowery et al. (2004) provide compelling documentation of the explosion in patents at and licenses by universities since passage of the Bayh-Dole act.

The second view or understanding of what is meant by 'entrepreneurship' revolves around the organisational status of the firm or individual (Audretsch et al., 2015). According to this view, a firm is characterised as being entrepreneurial if it is small, based on employment, sales or assets criteria, or new, based on its age. Similarly, an individual is classified as being entrepreneurial if she has the status of owning a business, starting a business, or intending to start a business.

The link between technology transfer and entrepreneurship is less compelling based on the organisational view of entrepreneurship. According to Markman et al. (2005), only $20.5 \%$ of the offices of technology transfer surveyed included 'new venture creation' in their mission statement. Similarly, there is only a paucity of new ventures and startups measured in the AUTUM database. Using the organisational view of entrepreneurship, the role in and impact of universities on entrepreneurship is meagre and disappointing Lockett et al., 2003).

The third view of entrepreneurship in the scholarly literature revolves around performance (Audretsch et al., 2015). According to this view, a firm or organisation is considered to be entrepreneurial on the basis of its performance. Performance is typically measured in terms of a desired outcome, such as innovation or growth. The performance criterion of an intended social contribution is the basis for social entrepreneurship.

Based on the performance view of entrepreneurship, there is a strong link between university technology transfer and entrepreneurship. Numerous studies have documented the important role that university research and human capital generated at universities plays in innovative activity (Jaffe, 1989; Acs et al., 1992).

Thus, the impact of university of technology transfer on entrepreneurship depends to a considerable degree upon the actual meaning and sense of what is meant by entrepreneurship. There is more empirical evidence that university technology transfer plays an important role in generating entrepreneurship according to the behavioural and performance views of entrepreneurship, but not necessarily from the organisational view of entrepreneurship. 


\section{Knowledge spillovers}

A very different conduit for impacting entrepreneurship involves not technology invented or created at a university purchased for commercialisation but rather knowledge which is created at a university but is not purchased through a financial transaction. Knowledge spillovers refer to knowledge that is created in one organisational context and is accessed and utilised by a different organisation at a cost less than the economic value of that knowledge.

Knowledge spills over, because as Arrow (1962) pointed out, it is neither excludable nor exhausted. Thus, individuals, organisations and firms can access knowledge created in other organisations and firms for their own use. Jaffe (1989), Acs et al. (1992), Jaffe et al. (1993), Audretsch and Stephan (1996) and Audretsch and Feldman (1996) find not only does knowledge spill over resulting in innovative activity in third-party firms but that such knowledge spillovers tend to be spatially localised within close geographic proximity of the knowledge source. These studies explicitly included universities as a source of knowledge and found that they are an important source of knowledge spillovers leading to innovative activity by companies.

The actual mechanisms by which knowledge spills over were not identified or detected in the literature on knowledge spillovers. Some scholars considered the knowledge simply to be 'in the air' and available to be accessed by third-party firms and other organisations simply as a result of geographic proximity (Romer, 1986).

Other scholars, however, were more dubious about the ability of organisations and companies investing in and creating new knowledge and ideas to actually commercialise those ideas themselves. Audretsch et al. (2006) refer to the knowledge filter as conditions impeding the automatic commercialisation and spill over of knowledge. Some of the conditions contributing to the knowledge filter were identified by Arrow (1962) as the uncertainty and asymmetries across individuals within an organisation in assessing the potential value of any particular new idea. Christensen (1997) documents the challenge confronting large corporations to actually take advantage and commercialise the opportunities accruing from ideas and knowledge generated by their own research and development.

Entrepreneurial startups, such as SAP, Intel and Apple all were fuelled from knowledge and ideas created in a different organisational context. Just as the important ideas upon which SAP was launched were actually created by employees at IBM, so too were the technology and prototypes for the personal computer developed by Steve Jobs at his startup, Apple computer, actually developed by Xerox (Audretsch, 2015).

The knowledge filter confronting universities not only is the result of the inherent characteristics of knowledge and ideas, but of course there is typically a legal mandate prohibiting non-for-profit universities from commercialising products and services for profit. Thus, even though the underlying technology for the sports drink Gatorade was developed at the University of Florida, and the ideas that eventually launched Google were developed by students at Stanford, the organisations in which the ideas and knowledge were created, universities, are prevented from actually commercialising those products. Just as in the case of private companies, new knowledge and ideas generated from research and human capital at a university can often only be commercialised through the start up of a new firm. 
The knowledge spillover theory of entrepreneurship attributes the motivation to become an entrepreneur not (just) to personal characteristics, attributes, proclivities and propensities, but the disparity in the valuation of a new idea or knowledge by an individual and the organisation investing in the creation of that knowledge. Not only does the knowledge spillover theory of entrepreneurship provide an explanation of why some people choose entrepreneurship while others abstain from it, it also explains why it matters - not just for the individuals and firms involved, but for the place, albeit a city, region or even country (Audretsch, 2015). In particular, entrepreneurship serves as a conduit for the spill over of knowledge and ideas from the organisation in which they are created to the (new) organisation where they become commercialised.

Systematic and comprehensive measurement of the extent and importance of knowledge spillover entrepreneurship from university research and knowledge remains elusive. Perhaps due to the newness of this theory, there are not yet comprehensive databases systematically identifying and measuring new firms started from knowledge and ideas. Still, there is both case study and also some systematical empirical evidence suggesting the primacy of knowledge spillover entrepreneurship as both a source of entrepreneurship but also a conduit for the spill over of ideas and knowledge created in the context of a university.

The AUTUM database identifying university spin-outs was created by asking university offices of technology transfer about their activities, efforts and outputs. As described in the previous suggestion, American universities report only a paucity of new firms being started through the offices of technology transfer. However, Aldridge and Audretsch $(2010,2011)$ undertook a series of studies based on a new database not asking universities but rather scientists themselves what they do in terms of commercialising their research. Based on their database of high performing scientists involved in cancer research, they found that one-in-four actually had started a company. This suggested prevalence for entrepreneurship from university scientists considerably higher than had been identified in studies based on the activities of the offices of technology transfer at universities.

A limitation of the Aldridge and Audretsch $(2010,2011)$ studies was the very narrow selection of highly performing scientists in one sole scientific field, cancer research. In an effort to expand the inclusion of both the scientists and the scientific fields, Audretsch et al. (2013) developed a web-based database identifying and measuring scientist entrepreneurship across a much greater spectrum of scientists and scientific fields. Their findings confirmed their earlier studies suggesting that the prevalence of scientist entrepreneurship is considerably greater than had been previously thought. For the entire sample of scientists, their study found that around $13 \%$ of the scientists had started a new company. However, they also found that the propensity for a scientist to engage in entrepreneurship varies considerably across scientific fields. In computer and network systems, the prevalence of entrepreneurship is $23.8 \%$. Similarly, in civil, mechanical, and manufacturing innovation, around $20 \%$ were classified as an entrepreneur. In environmental biology, however, only $4.6 \%$ of the scientists had started a new business, and just $6.2 \%$ of the scientists were entrepreneurs in particle and nuclear astrophysics.

Thus, there is at least some empirical evidence, both anecdotal as well as based on systematic data analyses, suggesting the knowledge spillover entrepreneurship is an important mechanism for generating both new entrepreneurs but also for innovation, competitiveness, employment and economic growth. 


\title{
4 Entrepreneurship capital
}

The third way in which universities are linked to entrepreneurship is through their contribution to entrepreneurship capital. Audretsch et al. (2006) defined entrepreneurship capital as a type of social capital (Coleman, 1988) that is conducive to entrepreneurship.

Putnam (2000) defines social capital as;

\begin{abstract}
"Whereas physical capital refers to physical objects and human capital refers to the properties of individuals, social capital refers to connections among individuals - social networks and the norms of reciprocity and trustworthiness that arise from them. In that sense social capital is closely related to what some have called 'civic virtue.' The difference is that 'social capital' calls attention to the fact that civic virtue is most powerful when embedded in a sense network of reciprocal social relations. A society of many virtues but isolated individuals is not necessarily rich in social capital."
\end{abstract}

While social capital endows an individual, organisation, or place with access to other people and organisations within a social context, entrepreneurship capital is a type of social capital that enhances the ability of individuals, organisations and places to behave entrepreneurial. What Saxenian (1994) describes as networks and linkages characterising Silicon Valley, can also be thought of as reflecting entrepreneurship capital;

"It is not simply the concentration of skilled labor, suppliers and information that distinguish the region. A variety of regional institutions - including Stanford University, several trade associations and local business organizations, and a myriad of specialized consulting, market research, public relations and venture capital firms - provide technical, financial, and networking services which the region's enterprises often cannot afford individually. These networks defy sectorial barriers; individuals move easily from semiconductor to disk drive firms or from computer to network makers. They move from established firms to startups (or vice versa) and even to market research or consulting firms, and from consulting firms back into startups. And they continue to meet at trade shows, industry conferences, and the scores of seminars, talks, and social activities organized by local business organizations and trade associations. In these forums, relationships are easily formed and maintained, technical and market information is exchanged, business contacts are established, and new enterprises are conceived... This decentralized and fluid environment also promotes the diffusion of intangible capabilities and understandings."

Universities can enhance entrepreneurship capital through at least two important ways. The first is through the education of not just nascent or potential entrepreneurs, but also a much broader spectrum of students spanning a wide range of academic subjects. It is these students who will go on not just to become entrepreneurs and start new firms but also to work, live and make both public and private decisions in actual communities. Understanding and recognising the significance of entrepreneurship facilitates entrepreneurship capital.

The second way is through attracting and nurturing diversity. Universities typically are comprised of a highly diverse and heterogeneous population of academics and students. Diversity enhances entrepreneurship capital by injecting heterogeneity in both thinking and backgrounds into a place, which has been shown to fuel entrepreneurship. 


\section{Conclusions}

The link between universities and entrepreneurship is anything but straightforward. This paper has identified three different ways that universities influence and shape entrepreneurship. While much of the entrepreneurship literature has focused on the contribution of universities to entrepreneurship through technology transfer, this may actually be less important and have less impact. Rather, it may be the role of the university in generating both knowledge spillover entrepreneurship and entrepreneurship capital that may ultimately prove to be the most significant and compelling.

\section{References}

Acs, Z.J., Audretsch, D.B. and Feldman, M.P. (1992) 'Real effects of academic research', American Economic Review, Vol. 82, No. 1, pp.363-367.

Aldridge, T., Audretsch, D.B. and Venkata, N.K. (2011) University Science Faculty Ventures into Entrepreneurship, US Small Business Administration, Washington, D.C.

Aldridge, T.T. and Audretsch, D.B. (2010) 'Does policy influence the commercialization route? Evidence from the National Institutes of Health Funded Scientists', Research Policy, Vol. 39, No. 5, pp.583-588.

Aldridge, T.T. and Audretsch, D.B. (2011) 'The Bayh-Dole act and scientist entrepreneurship', Research Policy, Vol. 40, No. 8, pp.1058-1067.

Association of University Technology Managers (2004) Recollections: Celebrating the History of AUTM and the Legacy of Bayh-Dole, Association of University Technology Managers, Deerfield, IL.

Arrow, K. (1962) 'Economic welfare and the allocation of resources for invention', in R.R. Nelson (Ed.): The Rate and Direction of Inventive Activity, pp.609-626, Princeton University Press, Princeton.

Audretsch, D.B. (2007) The Entrepreneurial Society, Oxford University Press, New York.

Audretsch, D.B. (2015) Everything in its Place: Entrepreneurship and the Strategic Management of Cities, Regions and States, Oxford University Press, New York.

Audretsch, D.B. and Feldman, M.P. (1996) 'R\&D spillovers and the geography of innovation and production', American Economic Review, Vol. 86, No. 3, pp.630-640.

Audretsch, D.B. and Stephan, P.E. (1996) 'Company-scientist locational links: the case of biotechnology', American Economic Review, Vol. 86, No. 3, pp.641-652.

Audretsch, D.B., Aldridge, T. and Nadella, V.K. (2013) University Science Faculty Ventures into Entrepreneurship, US Small Business Administration University, Audretsch Economic Research Bloomington, No. 409.

Audretsch, D.B., Boente, W. and Keilbach, M. (2006) 'Entrepreneurship capital and its impact on knowledge diffusion and economic performance', Journal of Business Venturing, Vol. 23, No. 6, pp.687-698.

Audretsch, D.B., Keilbach, M. and Lehmann, E. (2006) Entrepreneurship and Economic Growth, Oxford University Press, Oxford.

Audretsch, D.B.., Kuratko, D.F. and Link, A.N. (2015) 'Making sense of the elusive paradigm of entrepreneurship', Small Business Economics, DOI 10.1007/s11187-015-9663-z, forthcoming.

Christensen, C. (1997) The Innovator's Dilemma, Harvard Business Review Press, Boston.

Coleman, J. (1988) 'Social capital in the creation of human capital', American Journal of Sociology Supplement, Vol. 94, Supplement, pp.95-120.

Jaffe, A. (1989) 'Real effects of academic research', American Economic Review, Vol. 79, No. 5, pp.957-970. 
Jaffe, A., Traijtenberg, M. and Henderson, R. (1993) 'Geographic localization of knowledge spillovers as evidenced by patent citations', Quarterly Journal of Economics, Vol. 63, No. 3, pp.577-598.

Link, A. and Siegel, D. (2005) 'University-based technology initiatives: quantitative and qualitative evidence', Research Policy, Vol. 34, No. 3, pp.641-655, doi:10.1016/j.respol.2005.01.005.

Link, A., Siegel, D. and Bozeman, B. (2007) 'An empirical analysis of the propensity of academics to engage in informal university technololgy transfer', Industrial and Corporate Change, Vol. 16, No. 4, pp.641-655, doi:10.1093/icc/dtm020.

Lockett, A., Wright, M. and Franklin, S. (2003) 'Technology transfer and universities' sprin-out strategies', Small Business Economics, Vol. 20, No. 2, pp.185-201.

Markman, G., Phan, P., Balkin, D. and Gianiodis, P. (2005) 'Entrepreneurship and university-based technology transfer', Journal of Business Venturing, Vol. 20, No. 2, pp.241-263.

Mowery, D., Nelson, R., Sampat, B.and Ziedonis, A. (2004) Ivory Tower and Industrial Innovation: University-Industry Techology Transfer Before and After the Bayh-Dole Act, Stanford University Press, Stanford, CA.

Phan, P. and Siegal, D.S. (2006) 'The effectiveness of university technology transfer: lessons learned, managerial and policy implications, and the road forward', Foundations and Trends in Entrepreneurship, Vol. 2, No. 2, pp.77-144.

Putnam, R. (2000) Bowling Alone: The Collapse and Revival of American Community, Simon and Schuster, New York.

Romer, P. (1986) 'Increasing returns and long-run growth', Journal of Political Economy, Vol. 94, No. 5, pp.1002-1037.

Saxenian, A. (1994) 'Regional advantage: culture and competition in silicon valley and route 128', Political Economy, Harvard University Press, Cambridge, Vol. 94, No. 5, pp.1002-1037. 